\title{
Discussing the Place of Corequisites in Juvenile Correctional Education and GED Success
}

\author{
Jonathan Lollar
}

Cesar Bernal

\section{ABOUT THE AUTHORS}

Jonathan Lollar is a doctoral student in the Developmental Education Program, at Texas State University. He currently teaches Learning Frameworks (EDP 1350) at Texas State University. He also has a Master's in Applied Philosophy and Ethics from the Texas State University Department of Philosophy, where he taught Ethics and Society for four years.

Cesar Bernal is a staff member in the Testing and Evaluation Measurement Center, at Texas State University, San Marcos. He currently coordinates the Academic Testing for Students with Disabilities, serving students registered with the Office of Disability Services, at Texas State University.

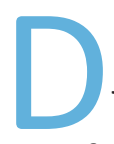

iscussions

surrounding juveniles, education programs, and recidivism are difficult to find. In fact, gathering data is incredibly difficult in juvenile facilities because of high turnover rates and difficulty of obtaining permission to conduct studies in juvenile facilities (Calderone, Bennett, Homan, Dedrick, \& Chatfield, 2009; Shippen, Morton, Flynt, Houchins, \& Smitherman, 2012). A study by David, Bozick, Steele, Saunders, and Miles found that participating in a GED or equivalent program reduced recidivism rates by $30 \%$ (2013). Assuming there is a relationship between juvenile recidivism rates and education programs, an important question remains. What types of education work best, and why? We believe a corequisite model paired with a philosophy course may be an important piece to this question.
A philosophy based corequisite approach has been developed for two primary reasons. The first being that pre-college philosophy classes have been shown to improve scores on the Cognitive Abilities Test 3-which tests verbal, non-verbal, and numerical reasoning (Topping \& Trickery, 2007). Philosophy majors also have the highest mean scores in verbal reasoning and analytic writing, as well as having the third highest mean score for quantitative reasoning (Education Testing Service, 2019). Some universities have even begun partnering with $\mathrm{K} 12$ schools in order to teach philosophy summer camps or instruct during normal school hours (Center for Philosophy for Children, 2019; Texas A\&M University, 2019). GED program completion is a major concern for juvenile detention centers, so it is important that critical thinking and reasoning skills are fostered. Philosophical discussion can certainly develop critical thinking and reasoning skills-with the bonus of increasing test taking skills.

The second primary reason for choosing a philosophy based corequisite approach is that research shows improving things like selfesteem, personal development, and a sense of empowerment, are all ways in which motivation to complete education programs amongst incarcerated adults is fostered (Baranger, Rousseau, Mastrorilli, \& Matesanz, 2018). Philosophy as a field is inundated with literature related to meaning making and values, selfrespect, classroom engagement, and identity (Locke, 1935; Boxill, 1976; hooks, 1994). After facilitating discussions on these topics and having students complete reflection assignments, students will learn the skills and foundations for cultivating and maintaining things like value, self-respect/self-esteem, and empowerment in their own lives (personally and academically). Students would be given the opportunity to speak, hear others, and experience validation through their own ideas.

The structure of the philosophy course will be simple. The course will focus on reading and writing skills through article readings, reflection papers, and narrative creation exercises (where students develop a case study to coincide with the discussion topic of the day). Dialogue is heavily utilized so that students can grapple with these concepts in a low stakes 
environment and build confidence, as well as watch their ideas and the ideas of others form.

We believe that a philosophy course that is taught alongside a GED class at a juvenile detention center will do much more than simply grant students an avenue for content centered application of their developing reading and writing skills. The content of the philosophy course will help students become more confident, as well as autonomous learners; this in turn will translate to higher GED completion and lower recidivism rates amongst juveniles.

\section{References}

Baranger, J., Rousseau, D., Mastrorilli, M., \& Matesanz, J. (2018). Doing time wisely: The social and personal benefits of higher education in prison. The Prison Journal, 98(4), 490-513. https://doi. org/10.1177/0032885518776380

Calderone, C., Bennett, S. V., Homan, S., Dedrick, R. F., \& Chatfield, A. (2009). Reaching the hard to reach: A comparison of two reading interventions with incarcerated youth. Middle Grades Research Journal, 4(3), 61-80. Retrieved from http:// libproxy.txstate.edu/login?url=http://search. ebscohost.com.libproxy.txstate.edu/login.aspx? direct=true $\& \mathrm{db}=$ eue $\& A N=45562612 \&$ site $=$ edslive \&scope=site

Center for Philosophy for Children (CPC). (2019). Empowering young people through philosophical inquiry. Retrieved from https://www.philosophyforchildren.org/

Davis, L. M., Bozick, R., Steele, J. L., Saunders, J., \& Miles, J. N. V. (2013). Evaluating the effectiveness of correctional education: A meta-analysis of programs that provide education to incarcerated adults. Santa Monica, CA: RAND Corporation.

Education Testing Service (ETS). (2019). GRE quide to the use of scores. Retrieved from https://www.ets. org/s/gre/pdf/gre guide.pdf

Fischer, B. (Ed.). (2017). College ethics: A reader on moral issues that affect you. Oxford, England: Oxford University Press.

hooks, b. (2003). Teaching to transgress: Education as the practice of freedom. New York, NY: Routledge.

Locke, A. (1935). Values and imperatives. In L. Harris (Ed.), The philosophy of Alain Locke: Harlem renaissance and beyond (pp.34-50). Philadelphia: Temple University Press.

Shippen, M. E., Morton, R. C., Flynt, S. W., Houchins, D. E., \& Smitherman, T. (2012). Efficacy of a computer-based program on acquisition of reading skills of incarcerated youth. Remedial and Special Education, 33, 14-22. https:// doi.org/10.1177/0741932510362512

Texas A\&M University (TAMU). (2019). P4C Texas philosophy for children at Texas A\&M. Retrieved from https://p4ctexas.sites.tamu.edu/

Topping, K. J., \& Trickey, S. (2007). Collaborative philosophical enquiry for school children: cognitive effects at 10-12 Years. British Journal of Educational Psychology, 77, 271-288. https://doi.org/10.1348/000709906X105328 